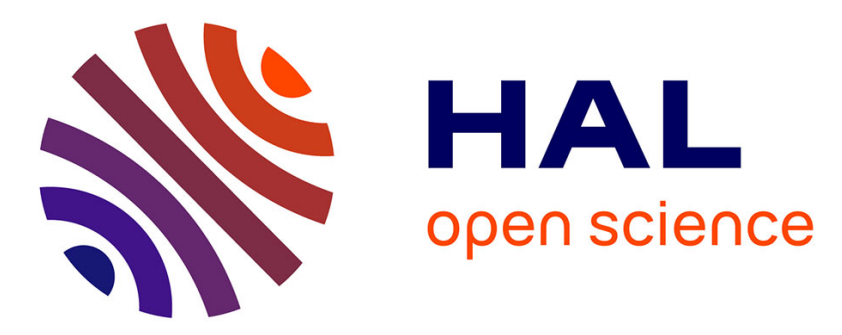

\title{
Bioremediation of halogenated compounds: comparison of dehalogenating bacteria and improvement of catalyst stability
}

Benjamin Erable, Isabelle Goubet, Sylvain Lamare, Marie-Dominique Legoy, Thierry Maugard

\section{To cite this version:}

Benjamin Erable, Isabelle Goubet, Sylvain Lamare, Marie-Dominique Legoy, Thierry Maugard. Bioremediation of halogenated compounds: comparison of dehalogenating bacteria and improvement of catalyst stability. Chemosphere, 2006, vol. 65, pp. 1146-1152. 10.1016/j.chemosphere.2006.04.007 . hal-00782648

\section{HAL Id: hal-00782648 \\ https://hal.science/hal-00782648}

Submitted on 30 Jan 2013

HAL is a multi-disciplinary open access archive for the deposit and dissemination of scientific research documents, whether they are published or not. The documents may come from teaching and research institutions in France or abroad, or from public or private research centers.
L'archive ouverte pluridisciplinaire HAL, est destinée au dépôt et à la diffusion de documents scientifiques de niveau recherche, publiés ou non, émanant des établissements d'enseignement et de recherche français ou étrangers, des laboratoires publics ou privés. 


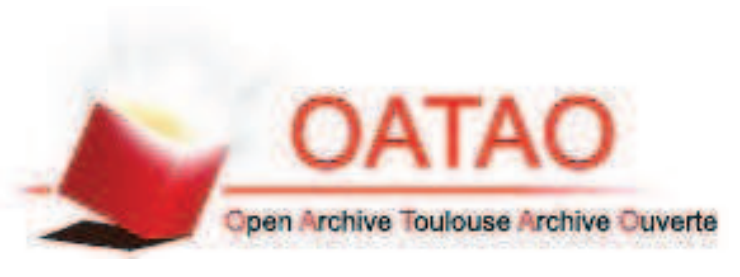

\section{Open Archive Toulouse Archive Ouverte (OATAO)}

OATAO is an open access repository that collects the work of Toulouse researchers and makes it freely available over the web where possible.

This is an author-deposited version published in: http://oatao.univ-toulouse.fr/ Eprints ID: 7883

To link to this article: DOI: $10.1016 /$ j.chemosphere.2006.04.007

URL: http://dx.doi.org/10.1016/j.chemosphere.2006.04.007

\section{To cite this version:}

Erable, Benjamin and Goubet, Isabelle and Lamare, Sylvain and Legoy, Marie-Dominique and Maugard, Thierry Bioremediation of halogenated compounds: comparison of dehalogenating bacteria and improvement of catalyst stability. (2006) Chemosphere, vol. 65 ( $\left.\mathrm{n}^{\circ} 7\right)$. pp. 1146-1152. ISSN 0045-6535

Any correspondence concerning this service should be sent to the repository administrator: staff-oatao@listes.diff.inp-toulouse.fr 


\title{
Bioremediation of halogenated compounds: Comparison of dehalogenating bacteria and improvement of catalyst stability
}

\author{
Benjamin Erable, Isabelle Goubet *, Sylvain Lamare, Marie-Dominique Legoy, \\ Thierry Maugard * \\ Laboratoire de Biotechnologies et de Chimie Bio-organique CNRS FRE 2766, Bâtiment Marie Curie, Université de La Rochelle, \\ Avenue Michel Crépeau 17042 La Rochelle cedex 1, France
}

\begin{abstract}
Five bacterial strains were compared for halogenated compounds conversion in aqueous media. Depending on the strain, the optimal temperature for dehalogenase activity of resting cells varied from 30 to $45^{\circ} \mathrm{C}$, while optimal $\mathrm{pH}$ raised from 8.4 to 9.0 . The most effective dehalogenase activity for 1-chlorobutane conversion was detected with Rhodococcus erythropolis NCIMB13064 and Escherichia coli BL21 (DE3) (DhaA). The presence of 2-chlorobutane or propanal in the aqueous media could inhibit the 1-chlorobutane transformation.
\end{abstract}

Keywords: Haloalkane dehalogenase; Rhodococcus erythropolis NCIMB13064; Sphingomonas paucimobilis UT26; Xanthobacter autotrophicus GJ10

\section{Introduction}

Halogenated compounds are an important class of environmental pollutants (Mohamed et al., 2002). Because of their toxicity, the bioremediation of these compounds has been widely studied and the biotechnological approach is now a promising field which could in the future supply reliable, simple and cheap technologies to treat halogenated pollutants contamination (Hardman, 1991).

Several articles have dealt with strains capable of hydrolytic dehalogenation of halohaliphatic compounds. The physiology, biochemistry and genetics of dehalogenating bacteria and substrates specificity of their enzymes are currently being studied (Janssen et al., 1985; Keuning et al., 1985; Hardman, 1991; Nagata et al., 1997; Janssen et al., 2001; Damborsky et al., 2001; Janssen, 2004).

\footnotetext{
* Corresponding authors. Tel.: +33 5 46458277; fax: +33 546458265 .

E-mail addresses: igoubet@univ-lr.fr (I. Goubet), tmaugard@univ-lr.fr (T. Maugard).
}

Xanthobacter autotrophicus GJ10 was one of the first isolated. This bacterium is able to use a number of halogenated short chain hydrocarbons as sole carbon source for growth (Janssen et al., 1985). Indeed it constitutively produces a haloalkane dehalogenase (DhlA) which catalyzes the hydrolytic dehalogenation of halogenated $\mathrm{C}_{2}-\mathrm{C}_{4}$ alkanes, including chlorinated, brominated and iodinated compounds (Keuning et al., 1985; Schanstra et al., 1996).

Other strains producing hydrolytic haloalkane dehalogenases belonging to the same family have been identified. $R$. erythropolis NCIMB13064 and Sphingomonas paucimobilis UT26 express respectively the DhaA (dehalogenase from $R$. erythropolis) and LinB (dehalogenase from S. paucimobilis) (Nagata et al., 1993; Curragh et al., 1994). The structure of these enzymes are very similar to the one of DhlA with some differences in the geometry and size of the active site cavity (Janssen, 2004). Nevertheless these three haloalkane dehalogenases differ by their substrate specificity and the bacteria producing these enzymes also differ in their range of growth 
substrate. Short chain 1-haloalkanes $\left(\mathrm{C}_{3}-\mathrm{C}_{10}\right)$ appear to be metabolized by $R$. erythropolis NCIMB13064 (Curragh et al., 1994) while Nagata et al. (1993) showed that not only short haloalkanes but also 1-chlorodecane and 2-chlorobutane, which are poor substrates for DhlA and DhaA, were good substrates for resting $E$. coli cells overproducing LinB dehalogenase. These strains could also be used for complementary degradation of mixture of halogenated pollutants.

The aim of this article is to compare the ability of these different strains and two recombinant $E$. coli strains to convert halogenated pollutants in a continuous gas/liquid reactor. Moreover, gaseous effluents can sometimes contain several halogenated compounds and very few studies have been dedicated to the study of competition of these different substrates for the catalyst. We also studied the influence of a secondary halogenated pollutant on the depollution efficiency of such reactor.

\section{Materials and methods}

\subsection{Microorganisms, culture conditions and chemicals}

R. erythropolis NCIMB13064, S. paucimobilis UT26, $X$. autotrophicus GJ10 and two recombinant strains of $E$. coli BL21 (DE3) the first containing the gene coding for the dehalogenase from $R$. erythropolis NCIMB13064 (E. coli BL21 (DE3) (DhaA)) and the second containing the gene coding for the dehalogenase from $X$. autotrophicus GJ10 (E. coli BL21 (DE3) (DhlA)) were used for this study.

$R$. erythropolis NCIMB13064 was obtained from the National Collection of Industrial and Marine Bacteria LTD, Aberdeen, Scotland. The organism was grown in 11 Erlenmeyer flasks sealed with Teflon line screw caps; the flasks contained $200 \mathrm{ml}$ of a minimal medium described by Sorkhoh et al. (1990) adjusted at pH 7.0. The medium was sterilized by autoclaving for $15 \mathrm{~min}$ at $121^{\circ} \mathrm{C}$. After cooling, $100 \mu \mathrm{l}$ of filtered sterilized 1 -chlorobutane $(0.22 \mu \mathrm{m}$ Minisart sartorius filters) was added twice as sole carbon source at $24 \mathrm{~h}$ interval. This method was chosen since it has been shown that adding twice $100 \mu \mathrm{l}$ of 1 -chlorobutane at $24 \mathrm{~h}$ interval, provide both a good growth and an interesting specific dehalogenase activity (Erable et al., 2004).

S. paucimobilis UT26 and X. autotrophicus GJ10 were grown in 11 aerobic flasks containing $200 \mathrm{ml}$ of Luria Bertani (LB) medium at $\mathrm{pH}$ 7.0. The LB medium had the following composition $\left(\mathrm{gl}^{-1}\right)$ : 10.0 Tryptone, 5.0 Yeast extract, and $5.0 \mathrm{NaCl}$. The medium was sterilized by autoclaving for $15 \mathrm{~min}$ at $121^{\circ} \mathrm{C}$.

E. coli BL21 (DE3) (DhlA) and E. coli BL21(DE3)(DhaA) were grown in 11 aerobic flasks containing $200 \mathrm{ml}$ of LB medium adjusted at $\mathrm{pH} 7.0$ and supplemented with $100 \mu \mathrm{g} \mathrm{ml}^{-1}$ ampicillin. The culture was incubated at $30{ }^{\circ} \mathrm{C}$ until it reached an $\mathrm{OD}_{690}$ of 0.7 after which it was induced with $0.4 \mathrm{mM}$ isopropyl- $\beta$-D-thiogalactopyranoside (IPTG).
All the bacterial cultures were incubated at $30{ }^{\circ} \mathrm{C}$ on an orbital shaker $(160 \mathrm{rpm})$. Cell growth was monitored by measuring the optical density at $690 \mathrm{~nm}$.

All substrates for culture media were purchased from Sigma Company (USA) except Tryptone and Yeast extract, which were obtained from Fluka (USA). All halogenated compounds: 1-chloropropane, 1-chlorobutane, 1-chloropentane, 1-chlorohexane, 1-chloroheptane, 1-chlorohexane, 1-chloroheptane, 1-chlorooctane, 1.2-dichloroethane, 1.2dibromoethane, 1-bromobutane, 1-bromopentane, 1-bromohexane, 1-iodobutane, 2-chlorobutane, 2-bromobutane and 1-propanol, propanal and propionic acid were purchased from Flucka (USA). Their purity was 99\%. Deionised water was obtained via a Milli-Q system (Millipore, France).

\subsection{Preparation of cells}

Cells grown for $24 \mathrm{~h}$ (E. coli BL21) or $48 \mathrm{~h}$ (R. erythropolis, S. paucimobilis, X. autotrophicus) were harvested by centrifugation (8000 rpm for $10 \mathrm{~min}$ ), washed with $50 \mathrm{mM}$ Tris/ $\mathrm{HCl}$ buffer at $\mathrm{pH} 8.4$ (S. paucimobilis) $\mathrm{pH}$ 8.5 (X. autotrophicus and the corresponding E. coli BL21 (DE3) (DhlA)) or at pH 9.0 ( $R$. erythropolis and the corresponding $E$. coli BL21 (DE3) (DhaA)) and resuspended in $50 \mathrm{mM}$ Tris/ $\mathrm{HCl}$ buffer at the same $\mathrm{pH}$ and at an approximate $\mathrm{OD}_{690}$ of 15 .

\subsection{Dehalogenation in a batch system}

The haloalkane dehalogenase activity of resting cells was assayed at $30^{\circ} \mathrm{C}$ in $50 \mathrm{mM}$ Tris $\mathrm{HCl}$ buffer $(\mathrm{pH} 8.4,8.5$ or 9.0). Tests were performed with $50 \mathrm{ml}$ of diluted cell suspension (approximate $\mathrm{OD}_{690}$ of 3 ) (in Tris/ $\mathrm{HCl}$ buffer) in $100 \mathrm{ml}$ bottles. Kinetics were started by the addition of $100 \mu \mathrm{l}$ of 1 -chlorobutane $\left(1.8 \mathrm{~g} \mathrm{l}^{-1}\right) .2 \mathrm{ml}$ was periodically sampled and cells were removed by centrifugation at $1000 \mathrm{rpm}$ for $2 \mathrm{~min} .1 \mathrm{ml}$ of the supernatant was assayed for butan-1-ol concentration by gas chromatography analysis using 1-hexanol as an internal standard and the same analytical conditions as for the analysis of the gas phase exiting the reactor.

\subsection{Dehalogenation in a continuous system}

The gas/liquid bioreactor consisted of a 11 flask Erlenmeyer containing $200 \mathrm{ml}$ of bacterial suspension at $5 \mathrm{~g}^{-1}$. Substrate feeding was obtained by passing nitrogen, used as a carrier gas, through substrate saturation flasks. Substrates were continuously passed through the bioreactor and reacted with the suspended resting cells. The gas leaving the bioreactor was analysed by gas chromatography. The acquisition and control of the operating parameters (substrate concentration, temperature, and pressure) were monitored on line as shown in Fig. 1. The vapour phase leaving the reactor was sampled using a $250 \mu$ loop on a six-way valve (Valco) maintained at $190{ }^{\circ} \mathrm{C}$. Samples 


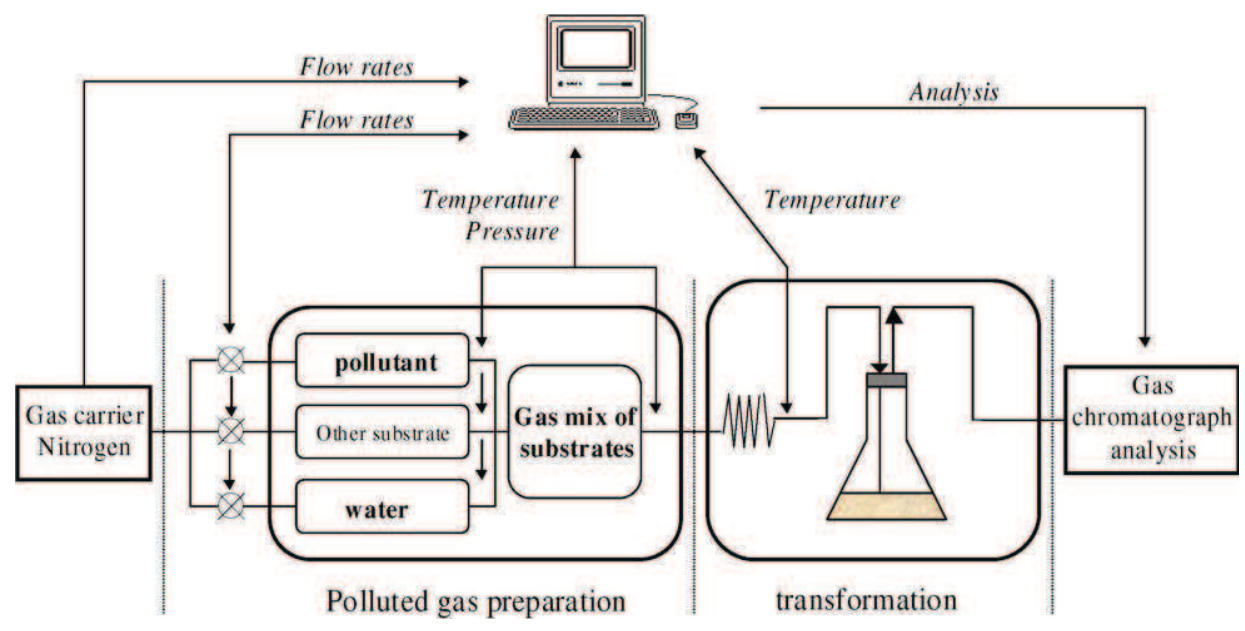

Fig. 1. Representation of the continuous gas/liquid bioreactor.

were automatically injected into the split injector of a gas chromatograph. Calibration for 1-chlorobutane and 1-butanol leaving the reactor were performed by sampling vapours generated with one of the saturation flask filled with 1-chlorobutane or 1-butanol and by programming increasing the vapour concentration of this substrate through an empty reactor.

A typical test was carried out at $30^{\circ} \mathrm{C}$, with $200 \mathrm{ml}$ of bacterial suspension at $5 \mathrm{~g}^{-1}$. The total flow passing into

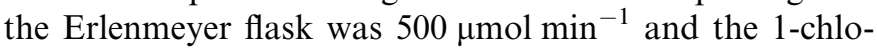
robutane flow was fixed at $17 \mu \mathrm{mol} \mathrm{min}^{-1}\left(1.5 \mathrm{mg} \mathrm{min}^{-1}\right)$. The dehalogenase activity was expressed in $\mu \mathrm{mol}$ of alcohol per min and per $g$ of cells.

\subsection{Chromatographic analysis}

Analysis were performed on a gas chromatograph (Hewlett Packard model 5890 A), equipped with a Flame Ionisation Detector (FID). The column used was an OV 1701 fused silica capillary column $(25 \mathrm{~m} \times 0.25 \mathrm{~mm}$ i.d. $\times 0.25 \mu \mathrm{m}$ film thickness; Chrompack, France). The split ratio was $43.2 / 2.7$. The injector was kept at $200{ }^{\circ} \mathrm{C}$, and the detector was kept at $250{ }^{\circ} \mathrm{C}$. The column temperature was held at $60^{\circ} \mathrm{C}$ for $2 \mathrm{~min}$, then programmed to increase at $10^{\circ} \mathrm{C} \min ^{-1}$ to $140{ }^{\circ} \mathrm{C}$. Nitrogen was used as a carrier gas and the flow rate in the column was $2.1 \mathrm{ml} \mathrm{min}{ }^{-1}$. Hydrogen and air were supplied to the FID at 40 and $400 \mathrm{ml} \mathrm{min}^{-1}$ respectively. Quantitative data were obtained after integration on a HP 3396A integrator.

\section{Results and discussion}

\subsection{Comparison of dehalogenating bacteria}

DhlA and LinB were constitutively produced by $X$. autotrophicus GJ10 and S. paucimobilis UT26 respectively. The expression of DhaA was induced by 1-chlorobutane addition for $R$. erythropolis NCIMB13064 cells. DhlA and DhaA produced by the recombinant $E$. coli BL21 were induced by IPTG (Table 1).

The generation time depended on the strain considered (Table 1). R. erythropolis NCIMB13064 possessed the highest generation time (310 $\mathrm{min})$. However, this was also the only strain cultivated on mineral medium supplemented with 1-chlorobutane. After growth, the cells were recovered and tested for the degradation of 1-chlorobutane. The effects of several parameters such as temperature, $\mathrm{pH}$ or substrate concentration were first observed on the dehalogenase activities of resting cells (Table 2).

The optimal temperature for the dehalogenase activity of $R$. erythropolis NCIMB13064 resting cells was $45^{\circ} \mathrm{C}$. Stafford (1993) determined an optimal temperature of $45^{\circ} \mathrm{C}$ for the free DhaA. The optimal temperature for dehalogenating activity of these resting cells corresponds to the optimal temperature of the free enzyme rather than to the optimal temperature for the growth of this microorganism $\left(28^{\circ} \mathrm{C}\right)$. The dehalogenase activity from $E$. coli BL21 (DE3) (DhaA) is more sensitive to the temperature than that observed in the strain of origin since $40^{\circ} \mathrm{C}$ was

Table 1

List of selected bacteria and media used to produce the different dehalogenases

\begin{tabular}{|c|c|c|c|c|}
\hline Bacterial strain & Dehalogenase & Growth medium & Added substrate & $\begin{array}{l}\text { Mean generation } \\
\text { time (min) }\end{array}$ \\
\hline R. erythropolis NCIMB13064 & DhaA & Mineral & 1-Chlorobutane & 310 \\
\hline E. coli BL21 (DE3) (DhaA) & DhaA & Luria Bertani & IPTG & 40 \\
\hline$X$. autotrophicus $\mathrm{GJ} 10$ & DhlA & Luria Bertani & / & 48 \\
\hline E. coli BL21 (DE3) (DhaA) & DhlA & Luria Bertani & IPTG & 38 \\
\hline S. paucimobilis UT26 & $\operatorname{Lin} B$ & Luria Bertani & / & 39 \\
\hline
\end{tabular}


Table 2

Optimal physicochemical parameters for the dehalogenase activity of resting cells

\begin{tabular}{|c|c|c|c|c|}
\hline Bacterial strain & $\begin{array}{l}\text { Optimal temperature } \\
\text { for dehalogenase } \\
\text { activity }\left({ }^{\circ} \mathrm{C}\right)\end{array}$ & $\begin{array}{l}\text { Optimal pH for } \\
\text { dehalogenase activity }\end{array}$ & $K_{\mathrm{m}}(\mathrm{mM})$ & $\begin{array}{l}\text { Maximal rate } \\
\text { of 1-chlorobutane } \\
\text { transformation } \\
\left(\mu \mathrm{mol} \mathrm{min}^{-1} \mathrm{~g}^{-1}\right)\end{array}$ \\
\hline R. erythropolis NCIMB13064 & 45 & 9.0 & 3 & 16 \\
\hline E. coli BL21 (DE3) (DhaA) & 40 & 9.0 & 5 & 23 \\
\hline$X$. autotrophicus GJ10 & 30 & 8.5 & 15 & 6 \\
\hline E. coli BL21 (DE3) (DhlA) & 30 & 8.5 & 19 & 9 \\
\hline S. paucimobilis UT26 & 35 & 8.4 & 23 & 23 \\
\hline
\end{tabular}

The tests of transformation of the 1-chlorobutane were carried out in Tris/HCl $50 \mathrm{mM}$ buffer at the optimal pH for each strain. The concentration of 1-chlorobutane varied from 0 to $20 \mathrm{mM}$. The production of butan-1-ol was measured by GC.

its optimal temperature. In the case of $X$. autotrophicus GJ10, E. coli BL21 (DE3) (DhlA) and $S$. paucimobilis UT26, optimal temperatures of whole cells dehalogenase activities corresponded to those generally published for the purified enzyme (Janssen et al., 1985; Nagata et al., 1997). It should be noted that an increase of $5{ }^{\circ} \mathrm{C}$ above the optimal temperature involved a $50 \%$ loss of the activity for the resting cells.

The optimum $\mathrm{pH}$ varied from 8.4 to 9.0 depending on the strain (Table 2). Various studies with free dehalogenases report similar data (Keuning et al., 1985; Nagata et al., 1997; Dravis et al., 2000). Under these optimal conditions (temperature and $\mathrm{pH}$ ), all the studied strains could transform 1-chlorobutane but maximal rates of conversion were different. Indeed, the more efficient dehalogenating bacteria were E. coli BL21 (DE3) (DhaA) and S. paucimobilis UT26 with a maximal transformation velocity of $23 \mu \mathrm{mol} \mathrm{min}{ }^{-1} \mathrm{~g}^{-1}$ (Table 2).

However, E. coli BL21 (DE3) (DhaA) had higher affinity for 1-chlorobutane than $S$. paucimobilis UT26 $(\mathrm{Km}=5$ and $23 \mathrm{mM}$ respectively). In contrast, $X$. autotrophicus GJ10 was less effective with a $6 \mu \mathrm{mol} \mathrm{min} \mathrm{m}^{-1} \mathrm{~g}^{-1}$ rate of 1-chlorobutane conversion. The 1 -chlorobutane is not the best substrate for all the studied strains but it is often used as a reference substrate. DhlA from $X$. autotrophicus GJ10 is better known for its affinity for short dihalogenated substrates such as 1.2-dichloroethane or 1.2-dibromoethane whereas LinB from $S$. paucimobilis is known for its affinity for mono-halogenated substrates $\left(\mathrm{C}_{4}-\mathrm{C}_{10}\right)$ (Damborsky and Koca, 1999).

Since the behavior of the free dehalogenases varies with respect to the substrates, the dehalogenating activity of resting cells was also tested with different substrates. All strains tested were active on the brominated, chlorinated and iodinated compounds selected. Except for 1-chloropropane, the short chain compounds were better transformed in aqueous medium than those with long carbon chain. For almost all strain, 1-chlorobutane was better transformed than 1-chloropentane which was better degraded than 1-chlorohexane. The same trend was noticed for brominated compounds. This observation can be directly connected to the aqueous solubility of the compounds. However S. paucimobilis UT26 is more active than the other strains for the long chain compounds $\left(\mathrm{C}_{6}-\mathrm{C}_{10}\right)$. Except for
S. paucimobilis resting cells, rate of conversion of 1-bromohexane was always higher than that of 1-chlorohexane. These data observed with whole cells are in agreement with those reported for the purified enzymes (Janssen et al., 1985; Stafford, 1993; Damborsky, 1996). But the reverse trend can be observed when comparing rates of conversion of 1-bromobutane and 1-chlorobutane or 1-bromopentane and 1chloropentane. Only $S$. paucimobilis UT26 was able to transform secondary mono-halogenated compounds such as 2-chlorobutane with rates comparable to those of 1-chlorobutane degradation. $X$. autotrophicus GJ10 clearly showed a specificity for short dihalogenated compounds such as 1.2-dichloroethane or 1.2-dibromoethane.

\subsection{Continuous dehalogenation in a gas/liquid bioreactor}

We observed in the preceding study that the cells of E. coli BL21 (DE3) (DhaA) could be useful in the bioremediation of the 1-chlorobutane. Indeed, the kinetic parameters obtained in batch reaction for resting cells (dehalogenating activity $=23 \mu \mathrm{mol} \mathrm{min} \mathrm{m}^{-1} \mathrm{~g}^{-1}$ and $\mathrm{Km}=$ $5 \mathrm{mM}$ ) and the low generation time of this strain (40 $\mathrm{min}$ ) could be interesting for the transformation of 1-chlorobutane. Consequently, fresh harvested E. coli BL21 (DE3) (DhaA) cells were tested in a continuous gas/liquid bioreactor for the transformation of 1-chlorobutane (Fig. 1). We observed that it is not possible to preserve a stable dehalogenase activity when resting cells were placed in a standard Tris/ $\mathrm{HCl} 50 \mathrm{mM}$, pH 9.0 buffer (Fig. 2). Maximal dehalogenase activity was detected after only $50 \mathrm{~h}$ of reaction. Rate of conversion then decreased and no activity was detected after $400 \mathrm{~h}$ of reaction. The rate of deactivation was found to be $0.3 \%$ maximal activity per hour.

This low stability of the dehalogenase activity was already observed in batch system with free dehalogenases. The hydrolysis of 1-chlorobutane produces both butan1-ol and $\mathrm{HCl}$. This acid is known to have two effects: acidifying the medium (by $\mathrm{H}^{+}$) and inhibiting dehalogenase (by $\mathrm{Cl}^{-}$) (Oakley et al., 2002). The presence of an alcohol produced by the hydrolysis of halogenated compounds or the products of its metabolism (alcohol $\rightarrow$ aldehyde $\rightarrow$ carboxylic acid) could also have an effect on the dehalogenase activity of resting cells. 


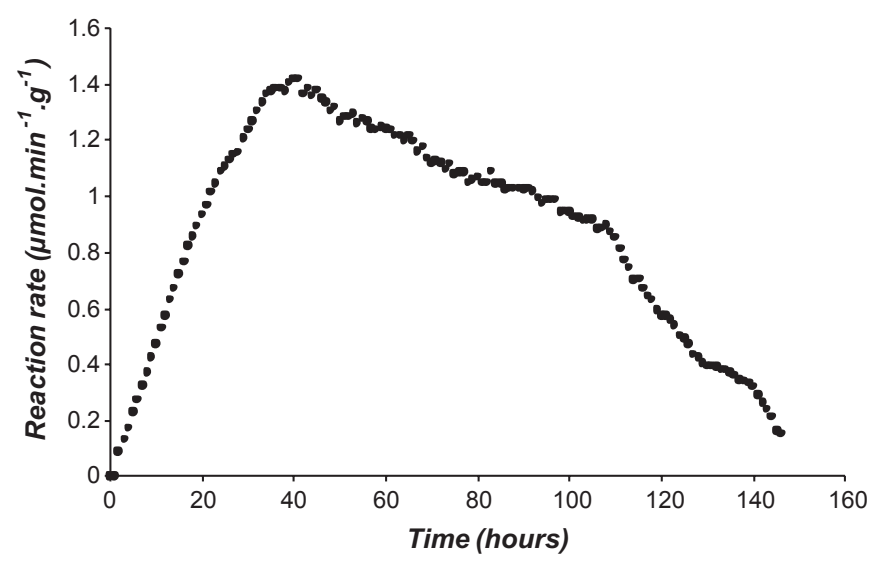

Fig. 2. Continuous 1-chlorobutane transformation by resting cells of E. coli BL21 (DE3) (DhaA) at $40{ }^{\circ} \mathrm{C}$. Dehalogenase activity is expressed as the 1-chlorobutane transformation $\left(\mu \mathrm{mol} \mathrm{min} \mathrm{m}^{-1} \mathrm{~g}^{-1}\right.$ of bacteria).

\subsection{Effect of the addition of an alcohol, an aldehyde or an acid on conversion of 1-chlorobutane by resting cells}

Consequently, we examined the effect of secondary products resulting from the hydrolysis of 1-chloropropane (propanol, propanal, propionic acid) on the dehalogenase activity of whole cells (Fig. 3). Propanol, propanal and pro-
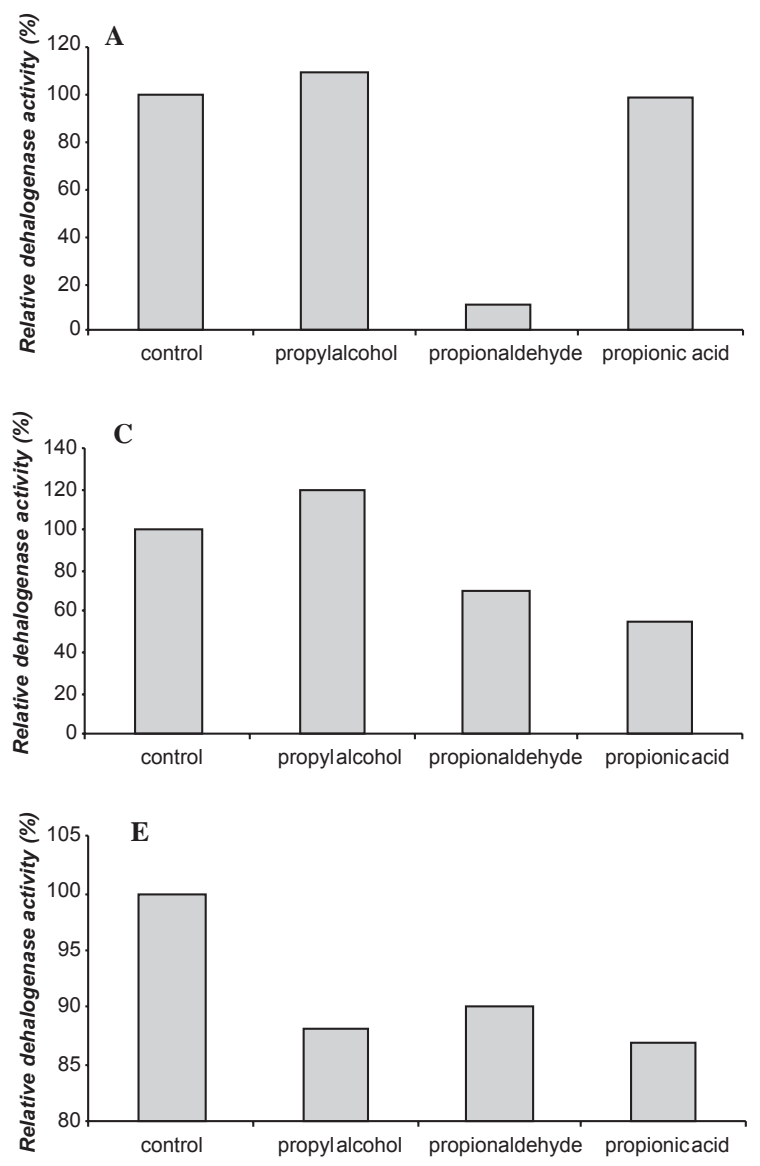

pionic acid were used as effectors for reasons of separation and solubility. Propanol, propanal or propionic acid were added in the reaction medium at a concentration of $2 \mathrm{ml}^{-1}$ and butan-1-ol production was determined, using 1-chlorobutane as a substrate.

First of all, the presence of propanol in the reaction medium had no significant effect on the velocity of 1-chlorobutane transformation in butan-1-ol. The propanal had a more important effect on the dehalogenase activity. This could be due the toxicity of the aldehyde. Cells of $R$. erythropolis NCIMB13064 were the most sensitive to the presence of propanal in the medium. Indeed $95 \%$ of the dehalogenase activity of $R$. erythropolis was inhibited in the presence of propanal at a concentration of $2 \mathrm{ml} \mathrm{l}^{-1}$. A similar effect was noticed in the presence of propanoic acid except in the case of $R$. erythropolis cells.

\subsection{Effect of 2-chlorobutane on conversion of 1-chlorobutane by resting cells}

Gaseous effluents can contain a mixture of pollutants and the treatment of several halogenated compounds by biological method is even more difficult than the degradation of a single halogenated pollutant. 2-chlorobutane is a recalcitrant substrate for the majority of the strains stud-
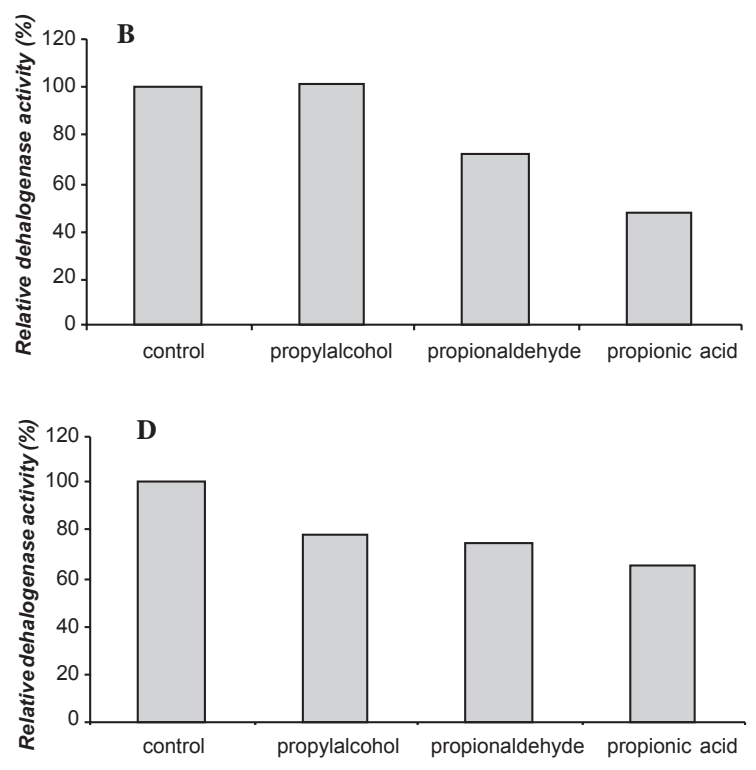

Fig. 3. The effect of propanol, propanal and propionic acid on resting cells dehalogenase activity. The tests of transformation of the 1-chlorobutane were carried out in Tris/ $\mathrm{HCl} 50 \mathrm{mM}$ buffer. The temperature and $\mathrm{pH}$ were those determined as optimal for each strain. The concentration of 1 -chlorobutane was $14 \mathrm{mM}$ and the concentration of secondary product was 2/1000 (v/v). The production of butan-1-ol was measured by GC. 
Table 3

Relative dehalogenase activity of the different resting cells

\begin{tabular}{|c|c|c|c|c|c|}
\hline & $\begin{array}{l}\text { R. erythropolis } \\
\text { NCIMB } 13064\end{array}$ & $\begin{array}{l}\text { E. coli BL21 } \\
\text { (DE3) (DhaA) }\end{array}$ & $\begin{array}{l}X \text {. autotrophicus } \\
\text { GJ10 }\end{array}$ & $\begin{array}{l}\text { E. coli BL21 } \\
\text { (DE3) (DhlA) }\end{array}$ & $\begin{array}{l}\text { S. paucimobilis } \\
\text { UT26 }\end{array}$ \\
\hline Experimental conditions & $30{ }^{\circ} \mathrm{C}, \mathrm{pH} 9.0$ & $30{ }^{\circ} \mathrm{C}, \mathrm{pH} 9.0$ & $30^{\circ} \mathrm{C}, \mathrm{pH} 8.5$ & $30^{\circ} \mathrm{C}, \mathrm{pH} 8.5$ & $30^{\circ} \mathrm{C}, \mathrm{pH} 8.4$ \\
\hline 1-Chloropropane & $50(48)$ & 44 & $75(165)$ & 116 & $30(135)$ \\
\hline 1-Chlorobutane & $100(100)$ & 100 & $100(100)$ & 100 & $100(100)$ \\
\hline 1-Chloropentane & $82(78)$ & 56 & $18(16)$ & 4 & $56(120)$ \\
\hline 1-Chlorohexane & $25(75)$ & 19 & $5(10)$ & 1 & $60(145)$ \\
\hline 1-Chloroheptane & ND (59) & 7 & $0(0)$ & 0 & $70(161)$ \\
\hline 1-Chlorooctane & $5(33)$ & 2 & $0(0)$ & 0 & 76 (139) \\
\hline 1-Chlorodécane & ND (10) & 0 & 0 (ND) & 0 & $8(27)$ \\
\hline 1-Bromobutane & 99 (106) & 144 & $82(87)$ & 102 & $56(234)$ \\
\hline 1-Bromopentane & $58(51)$ & 35 & 67 (ND) & 145 & $28(355)$ \\
\hline 1-Bromohexane & $45(32)$ & 20 & 37 (ND) & 114 & 13 (ND) \\
\hline 1-Iodobutane & $47(58)$ & 137 & 34 (ND) & 30 & 67 (ND) \\
\hline 2-Chlorobutane & $8(8)$ & 2 & 0 (ND) & 0 & 73 (ND) \\
\hline 2-Bromobutane & $34(52)$ & 47 & 0 (ND) & 18 & 99 (ND) \\
\hline 1,2-Dichloroéthane & ND (ND) & 66 & $159(323)$ & 223 & 10 (ND) \\
\hline 1,2-Dibromoéthane & ND (ND) & 211 & $116(303)$ & 200 & 201 (ND) \\
\hline
\end{tabular}

The tests were carried out in Tris/HCl $50 \mathrm{mM}$ buffer. The temperature and $\mathrm{pH}$ are those determined as optimal for each strain. The concentration of substrates in the reaction medium is $10 \mathrm{mM}$. The production of corresponding alcohol is evaluated in the course of time by GC. Rate of degradation of 1 -chlorobutane is taken as the reference $(100 \%)$.

The values between brackets are reported from the literature and represent values already observed with the purified dehalogenase (Janssen et al., 1985; Stafford, 1993; Damborsky, 1996).

ND: Not determined.

Table 4

The effect of inhibitor (2-chlorobutane) on resting cells dehalogenase activity for 1-chlorobutane

\begin{tabular}{|c|c|c|c|c|}
\hline $\begin{array}{l}\text { 2-chlorobutane } \\
\text { concentration }(\mathrm{mM})\end{array}$ & $\begin{array}{l}\text { R. erythropolis } \\
\text { NCIMB } 13064\end{array}$ & $\begin{array}{l}\text { E. coli } \mathrm{BL} 21 \\
\text { (DE3) (DhaA) }\end{array}$ & $\begin{array}{l}\text { X. autotrophicus } \\
\text { GJ10 }\end{array}$ & $\begin{array}{l}\text { E. coli } \text { BL21 } \\
\text { (DE3) (DhlA) }\end{array}$ \\
\hline 0 & 100 & 100 & 100 & 100 \\
\hline 6 & 95 & 82 & 90 & 85 \\
\hline 14 & 91 & 71 & 81 & 77 \\
\hline 19 & 84 & 51 & 77 & 63 \\
\hline
\end{tabular}

The tests of transformation of the 1-chlorobutane were carried out in Tris/HCl $50 \mathrm{mM}$ buffer. The temperature and pH were those determined as optimal for each strain. The concentration of 1-chlorobutane was $14 \mathrm{mM}$. The production of butan-1-ol was measured by GC.

ied (Table 3), only S. paucimobilis UT26 has a good affinity for this compound. We studied the influence of 2-chlorobutane on the transformation of the 1-chlorobutane by resting cells (Table 4).

The dehalogenase activity of the various strains with exception of $S$. paucimobilis UT26 was measured for increasing concentrations of 2-chlorobutane. The dehalogenase activity of resting cells was inversely proportional to the concentration of 2-chlorobutane. E. coli BL21 was the most sensitive strain to 2-chlorobutane. Half of the initial dehalogenase activity of these cells was inhibited by the presence of $19 \mathrm{mM}$ of 2-chlorobutane.

\section{Conclusions}

The study in aqueous phase made it possible to define the optimal temperature and $\mathrm{pH}$ conditions for dehalogenase activity of resting cells. For the transformation of the 1chlorobutane, two strains have a strong effectiveness: $R$. erythropolis NCIMB13064 and E. coli BL21 (DE3) (DhaA). Production of the cells of E. coli BL21 (DE3)
(DhaA) is eight times faster than that of $R$. erythropolis NCIMB13064 and should also be preferred for remediation. However the use of E. coli BL21 (DE3) (DhaA) for the continuous conversion of 1-chlorobutane is limited by the low stability of its dehalogenase activity. The studied strains have different specificities for halogenated substrates and thus the association of these strains could be interesting to treat a broad range of halogenated compounds. Since the optimal $\mathrm{pH}$ and temperature differ depending on the strain, they should be used in successive batch reactor rather than in association.

\section{Acknowledgements}

We thank Prof. D.B. Janssen (Department of Biochemistry, Groningen Biotechnology Center, University of Groningen) for providing us $X$. autotrophicus GJ10 and the two E. coli BL21 strains and are grateful to Pr. Damborsky (Protein Engineering Group, Faculty of Science, Masaryk University) for providing us the $S$. paucimobilis UT26 strain. 
This work was supported by an ADEME/Région Poitou Charentes grant.

\section{References}

Curragh, H., Flynn, O., Larkin, M.J., Stafford, T.M., Hamilton, J.T., Harper, D.B., 1994. Haloalkane degradation and assimilation by Rhodococcus rhodochrous NCIMB13064. Microbiology 140, 14331442.

Damborsky, J., 1996. A mechanistic approach to deriving quantitative structure-activity relationship models for microbial degradation of organic compounds. SAR QSAR Environ. Res. 5, 27-36.

Damborsky, J., Koca, J., 1999. Analysis of the reaction mechanism and substrate specificity of haloalkane dehalogenases by sequential and structural comparisons. Protein Eng. 12, 989-998.

Damborsky, J., Rorije, E., Jesenka, A., Nagata, Y., Klopman, G., Peijnenburg, W.J., 2001. Structure-specificity relationships for haloalkane dehalogenases. Environ. Toxicol. Chem. 20, 26812689.

Dravis, B.C., Lejeune, K.E., Hetro, A.D., Russel, A.J., 2000. Enzymatic dehalogenation of gas substrates with haloalkane dehalogenase. Biotechnol. Bioeng. 69, 235-241.

Erable, B., Goubet, I., Lamare, S., Legoy, M.D., Maugard, T., 2004. Haloalkane hydrolysis by Rhodococcus erythropolis cells: A comparison of conventional aqueous phase dehalogenation and non-conventional gas phase dehalogenation. Biotechnol. Bioeng. 86, 47-54.

Hardman, D.J., 1991. Biotransformation of halogenated compounds. Crit. Rev. Biotechnol. 11, 1-40.

Janssen, D.B., Scheper, A., Dijkhuizen, L., Witholt, B., 1985. Degradation of halogenated aliphatic compounds by Xanthobacter autotrophicus GJ10. Appl. Environ. Microbiol. 49, 673-677.
Janssen, D.B., Oppentocht, J.E., Poelarends, G.J., 2001. Microbial dehalogenation. Cur. Opin. Biotechnol. 12, 254-258.

Janssen, D.B., 2004. Evolving haloalkane dehalogenases. Curr. Opin. Chem. Biol. 8, 150-159.

Keuning, S., Janssen, D.B., Witholt, B., 1985. Purification and characterization of hydrolytic haloalkane dehalogenase from Xanthobacter autotrophicus GJ10. J. Bacteriol. 163, 635-639.

Mohamed, M.F., Kang, D., Aneja, V.P., 2002. Volatile organic compounds in some urban locations in United States. Chemosphere 47, 863-882.

Nagata, Y., Nariya, T., Ohtomo, R., Fukuda, M., Takagi, M., 1993. Cloning and sequencing of a dehalogenase gene encoding an enzyme with hydrolase activity involved in the degradation of gammahexachlorocyclohexane in Pseudomonas paucimobilis. J. Bacteriol. $175,6403-6410$.

Nagata, Y., Miyauchi, K., Damborsky, J., Manova, K., Ansorgova, A., Takagi, M., 1997. Purification and characterization of haloalkane dehalogenase of a new substrate class from a hexachlorohexane degrading bacterium, sphingomonas paucimobilis UT26. Appl. Environ. Microbiol. 63, 3707-3710.

Oakley, A.J., Prokop, Z., Bohac, M., Kmunicek, K.J., Jedlicka, T., Monincova, M., Kuta-Smatanova, I., Nagata, Y., Damborsky, J., 2002. Exploring the structure and activity of haloalkane dehalogenase from Sphingomonas paucimobilis UT26: evidence for product- and water-mediated inhibition. Biochemistry 41, 4847-4855.

Schanstra, J.P., Kingma, J., Janssen, D.B., 1996. Specificity and kinetics of haloalkane dehalogenase. J. Biol. Chem. 271, 14747-14753.

Sorkhoh, N.A., Ghannoum, M.A., Ibrahim, A.S., Stretton, R.J., Radwan, S.S., 1990. Growth of Candida albicans on hydrocarbons: influence on lipids and sterols. Microbiol. 64, 159-171.

Stafford, T.M., 1993. The microbial degradation of chloroalkanes. PhD Thesis, University of Belfast, Ireland. 